Original Article

\title{
IN VITRO PROPAGATION OF SHOOTS AND CALLUS INDUCTION OF GYMNEMA SYLVESTRE R. BR. “AN IMPORTANT ANTI-DIABETIC PLANT”
}

\author{
MOHSINA SYEDY*, KRISHNENDRA SINGH NAMA \\ Department of Life Sciences, Career Point University, Kota (Rajasthan) \\ Email: ali.mohsina.07@gmail.com
}

Received: 20 Jan 2018, Revised and Accepted: 08 Apr 2018

\begin{abstract}
Objective: The objective of this research was to establish and develop a protocol for the mass multiplication and callus induction of an anti-Diabetic plant-G. sylvestre R. Br.

Methods: Sterilized explants (Nodal segment and leaf) were used for the initiation of culture. They were cultured on MS medium supplemented with a variety of PGRs (BAP, Kn, IBA, 2,4-D) individually or in combinations.

Results: The induction of multiple shoots from nodal segments were highest in MS medium supplemented with $2.0 \mathrm{mg} / \mathrm{l} \mathrm{Kn}$ and in BAP Maximum shoots were obtained on MS medium fortified with $1 \mathrm{mg} / \mathrm{l} \mathrm{BAP}$. For rooting different concentration of IBA were used and highest rooting was recorded on MS medium supplemented with $2.0 \mathrm{mg} / \mathrm{l}$ IBA. The rooted Plantlets were hardened initially in culture room conditions and then transferred to mist house. Leaf petiole explants were used for the purpose of callus induction. Best growth was observed in MS medium supplemented with 2,4-D. $1.0 \mathrm{mg} / \mathrm{l}$ 2,4-D+0.5 mg/l BAP, $1.0 \mathrm{mg} / \mathrm{l}$ 2,4-D+1.5 mg/l Kn.
\end{abstract}

Conclusion: The results obtained in this research work clearly indicated that $\mathrm{Kn}$ is a better choice than BAP for the culture initiation. $2 \mathrm{mg} / \mathrm{l}$ IBA was proved best for root induction. For callus induction, $1 \mathrm{mg} / \mathrm{l}$ 2,4-D gave good results and when callus was sub-cultured on 2,4-D with BAP or Kn then $1.0 \mathrm{mg} / \mathrm{l}$ 2, 4-D+1.5 mg/l Kn proved best for mass propagation of callus.

Keywords: Shoot regeneration, Callus induction, Mist house, Auxiliary shoot proliferation

(C) 2018 The Authors. Published by Innovare Academic Sciences Pvt Ltd. This is an open access article under the CC BY license (http://creativecommons.org/licenses/by/4.0/) DOI: http://dx.doi.org/10.22159/ijcpr.2018v10i3.27340

\section{INTRODUCTION}

Gymnema sylvestre $\mathrm{R}$. Br. commonly known as "Gudmar" is a member of the family Asclepiadaceae. It is an important medicinal plant [1]. It is a large woody twinning shrub growing wildly running over the tops of trees in the forest. It possesses the property of paralyzing the sense of the taste of sweet materials for few hours. Flowering session of Gudmar is April and November and fruiting season is between December-March [2]. This plant is found largely in Deccan Peninsula, distributed in Asia, tropical Africa, Malaysia and Sri-lanka. It found in Gadariya Mahadeva, Mukundara hills National Park in Kota (Rajasthan), India. It is a rich source of secondary metabolites. It possesses good therapeutic activity. It is widely used in Unani medicine and as Rasayana in Ayurveda, an ancient system of Indian medicine. $G$. sylvestre are threatened with extinction due to its over-exploitation. Vegetative propagation is done by seed but its seed show low rate of germination and poor seed viability. So, alternative propagation methods would be beneficial for its largescale multiplication improvement and conservation of the plant.

Biotechnological methods are used to culture plant cells and tissues should provide new means of conserving and fast propagation of this medicinal plants $[3,4]$.

The aim of the present study was to develop multiple shoots regeneration of $G$. sylvestre under various concentrations of PGRs. This protocol also offers the rapid mass micropropagation and callus formation from the leaf petiole. For both purposes, Auxins (2, 4-D) and cytokinins (Kn, BAP) were used [5-7].

\section{MATERIALS AND METHODS}

About 5-6 cm branches of shoots of Gymnema sylvestre plant were collected from the Gadariya Mahadeva region of Kota, Rajasthan. The branches with nodal explants were washed in running tap water and then washed thoroughly by adding few drops of Tween-20 to remove the dust, fungal and bacterial spore contaminants over the leaves. Then explants were surface sterilized with $0.1 \% \mathrm{HgCl}_{2}$ solution for about 5 min followed by rinsing the explants five times with double distilled water inside the Laminar Air Flow chamber. Then nodal segments about $0.5-0.8 \mathrm{~cm}$ in size were prepared aseptically and were implanted vertically on MS medium supplemented with appropriate concentration of Cytokinins i.e. BAP, $\mathrm{Kn}$ (1.0-5.0 mg/l). Medium was prepared by the addition of these hormones individually and in combination. These medium is used for shoot induction. Same procedure was repeated for shoot multiplication. MS medium containing 3\% sucrose was solidified with $0.8 \%$ agar. The $\mathrm{pH}$ of media was adjusted to $5.9 \pm 0.02$ by using $1 \mathrm{~N} \mathrm{NAOH}$ or $1 \mathrm{~N}$ HCL solution before autoclaving of the medium. Media was poured in test tubes and conical flasks and then sterilized by autoclaving at $121^{\circ} \mathrm{C}$ and 15 psi pressure for $15-20 \mathrm{~min}$.

Then this sterilized MS medium was used for culture. After inoculation of explants, the culture was incubated under temperature range $\left(25 \pm 2{ }^{\circ} \mathrm{C}\right)$, light intensity $(2000-2500$ lux for 16 $\mathrm{h} / \mathrm{d}$ provided by fluorescent tubes) and $60-70 \%$ humidity.

For each experiment, a minimum of 7 replicates was taken. Experiments were repeated thrice times and observations were recorded after an interval of $3 \mathrm{w}$. After the induction of shoots on medium, the shoots were subcultured on fresh medium containing desired plant hormones every $3 \mathrm{w}$. Plantlets were subculture on various concentrations and combinations of BAP and Kn. For the induction of root, MS fortified with IBA (Auxin) was used containing $1 / 4^{\text {th }}$ MS salts and $1.0 \%$ sucrose. Then in vitro rooted plantlets were transferred to culture bottles containing Soilrite (Soil: Sand: Peat moss). This mixture was irrigated with $1 / 4^{\text {th }}$ MS salt solution. Then these bottles were kept in controlled environmental conditions of culture room. After $3 \mathrm{w}$ of incubation, plantlets were transferred to mist house for further growth and development.

\section{RESULTS AND DISCUSSION}

The nodal explants, when inoculated on MS medium containing BAP and $\mathrm{Kn}$ in the range $1.0-5.0 \mathrm{mg} / \mathrm{l}$ showed enhanced shoot proliferation. Various combinations of Auxins and Cytokinins have 
been applied in the present context for callus and shoot induction from leaf and nodal explant of Gymnema sylvestre. BAP at its $1.0 \mathrm{mg} / \mathrm{l}$ concentration evoked the best response in shoot isolation from seed and explants. Shoots after their initial proliferation on medium containing $1.0 \mathrm{mg} / \mathrm{l}$ BAP were sub-cultured on same fresh medium after every $21 \mathrm{~d}$. Incorporation of BAP or Kn into MS medium supported multiplication of shoots in culture. In different concentrations of BAP (1.0-5.0 mg/l) Gymnema sylvestre gives best shooting response in $1.0 \mathrm{mg} / \mathrm{l}$ BAP (maximum no. of shoot $5.0 \pm 0.58$ and shoot length $3.4 \pm 1.1 \mathrm{~cm}$ ) (table 1, fig. 1-A and 2).

When explants were inoculated on Kn then the maximum number of shoots were obtained on its $2.0 \mathrm{mg} / \mathrm{l}$ concentration (maximum no. of shoot $3.0 \pm 1.5$ and shoot length $6.0 \pm 1.1 \mathrm{~cm}$ ) (table 2, fig. 1-B and 3). Kn proved to be a better choice than BAP.

The full or half strength of MS medium without any PGR was failed to induce rooting of regenerated shoots. However, shoots were capable to induce root when cultured on medium containing auxins.
Auxins in different concentration induced rooting when incorporated in the medium containing $1 / 4$ of MS salts.

In Gymnema sylvestre, $2.0 \mathrm{mg} / \mathrm{l}$ IBA proved to be best for in vitro rooting (Maximum no. of roots $2.52 \pm 0.5$ and root length $1.65 \pm 0.30 \mathrm{~cm}$ ). (table 3 , fig. 1-C and 3). In vitro rooted plantlets were initially hardened in culture room conditions where leaves expanded. After $3 \mathrm{w}$, the plantlets were shifted to mist house and then pot. There was an increase in the length of shoots and new leaves emerged which expanded quickly.

Leaf petiole explants were used for the purpose of callus induction. 2,4-D at its $1.0 \mathrm{mg} / \mathrm{l}$ concentration evoked best response (Maximum callus diameter $2.0 \mathrm{~cm}$ ) (table 4, fig. 1-D). After callus proliferation, it was sub-cultured on different combinations of Cytokines and Auxins. Variations in diameter of callus were observed. MS Medium fortified with Various concentrations of BAP with 2,4-D. $1.0 \mathrm{mg} / \mathrm{l} 2,4-\mathrm{D}+0.5$ $\mathrm{mg} / \mathrm{l} \mathrm{BAP}$ (Callus was whitish green, compact with $2.5 \mathrm{~cm}$ diameter) (table 5, 1-E), $1.0 \mathrm{mg} / \mathrm{l}$ 2,4-D+1.5 mg/l Kn (Callus was Whitish, compact with $2.6 \mathrm{~cm}$ diameter) (table $6,1-\mathrm{F}$ ).

Table 1: Effect of Cytokinin (BAP) on shoot proliferation from Nodal shoots explant of Gymnema sylvestre $\mathrm{R}$. Br

\begin{tabular}{llll}
\hline Hormone Con. (mg/l) & Response (\%) & $\begin{array}{l}\text { No. of Shoot/explant } \\
\text { (mean } \pm \text { SD) }\end{array}$ & Shoot length (in cm) (mean \pm SD) \\
\hline BAP & & $5.0 \pm 0.58$ & $3.4 \pm 1.1$ \\
1 BAP & 90 & $3.0 \pm 0.6$ & $2.5 \pm 0.5$ \\
3BAP & 70 & $2.0 \pm 0.4$ & $2.0 \pm 0.6$ \\
4BAP & 60 & $2.0 \pm 0.8$ & $1.5 \pm 0.62$ \\
\hline
\end{tabular}

Medium: MS+additives; mean \pm SD, $n=7$ replicates, Means having the same letter in each Colum do not different significantly at $\mathrm{P}<0.05$ (Tukey's test)

Table 2: Effect of cytokinin (Kn) on shoot proliferation from nodal shoot explant of Gymnema sylvestre $\mathrm{R}$. Br

\begin{tabular}{llll}
\hline Hormone Con. (mg/l) & Response (\%) & $\begin{array}{l}\text { No. of Shoot/explant } \\
\text { (mean } \pm \text { SD) }\end{array}$ & Shoot length (in cm) (mean \pm SD) \\
\hline Kn & 70 & $2.0 \pm 1.1$ & $4.25 \pm 0.5$ \\
$2 \mathrm{Kn}$ & 90 & $3.0 \pm 1.5$ & $6.0 \pm 1.1$ \\
$3 \mathrm{Kn}$ & 60 & $1.0 \pm 0.6$ & $2.0 \pm 0.1$ \\
$4 \mathrm{Kn}$ & 55 & $1.0 \pm 0.2$ & $1.2 \pm 0.2$ \\
\hline
\end{tabular}

Medium: MS+additives; mean \pm SD, $n=7$ replicates, Means having the same letter in each Colum do not different significantly at $\mathrm{P}<0.05$ (Tukey's test)

Table 3: Effect of auxin (IBA) on root induction from the isolated shoot of Gymnema sylvestre $\mathrm{R}$. Br

\begin{tabular}{llll}
\hline Hormone Con.(mg/l) & No. of roots/explants & Root length (in cm) & Rooting Response (\%) \\
\hline 1.0 IBA & $1.30 \pm 0.10$ & $0.90 \pm 0.10$ & 80 \\
2.0 IBA & $2.50 \pm 0.25$ & $1.65 \pm 0.30$ & 95 \\
3.0 IBA & $2.80 \pm 0.73$ & $0.51 \pm 0.05$ & 73 \\
\hline
\end{tabular}

Medium: MS+additives; mean \pm SD, $n=7$ replicates, Means having the same letter in each Colum do not different significantly at $\mathrm{P}<0.05$ (Tukey's test)

Table 4: Effect of Auxin (2, 4-D) on Callus induction by sub-cultured leaf explants of Gymnema sylvestre $\mathrm{R}$. Br

\begin{tabular}{lllll}
\hline Hormone Conc. (mg/l) & Callus diameter after $\mathbf{7}$ w subculture $\mathbf{( c m )}$ & $\begin{array}{l}\text { Callus proliferation } \\
\text { Scoring }\end{array}$ & Color of callus & Morphology of callus \\
\hline 2,4-D & & & Whitish & Highly fragile \\
1 2,4-D & 2.0 & +++ & Brownish Green & Frible \\
2 2,4-D & 1.0 & +++ & Brownish & Nodular \\
3 2,4-D & 0.5 & ++ & & \\
& & ++ & & \\
\hline
\end{tabular}

'++++' Intense, '+++' Moderate, '++' Meager

Table 5: Interactive effect of auxin (2,4-D) and cytokinine (BAP) on callus proliferation by sub-cultured callus of Gymnema sylvestre R. Br

\begin{tabular}{|c|c|c|c|c|}
\hline Hormone conc. (mg/l) & $\begin{array}{l}\text { Callus diameter after } 7 \mathrm{w} \\
\text { subculture }(\mathrm{cm})\end{array}$ & $\begin{array}{l}\text { Callus proliferation } \\
\text { scoring }\end{array}$ & Color of callus & $\begin{array}{l}\text { Morphology of } \\
\text { callus }\end{array}$ \\
\hline \multicolumn{5}{|l|}{ 2,4-D+BAP } \\
\hline $12,4-\mathrm{D}+0.5 \mathrm{BAP}$ & 2.5 & ++++ & Whitish Green & Compact \\
\hline $12,4-D+1.0$ BAP & 2.0 & +++ & Greenish & Frible \\
\hline \multirow[t]{2}{*}{1 2,4-D+1.5 BAP } & 1.5 & ++ & Brownish Green & Nodular \\
\hline & & +++ & & \\
\hline
\end{tabular}

'++++' Intense, '+++' Moderate, '++' Meager 
Table 6: Interactive effect of auxin (2,4-D) and cytokinine (Kn)on callus proliferation by sub-cultured callus of Gymnema sylvestre $\mathrm{R}$. Br

\begin{tabular}{|c|c|c|c|c|}
\hline $\begin{array}{l}\text { Hormone conc. } \\
(\mathrm{mg} / \mathrm{l})\end{array}$ & $\begin{array}{l}\text { Callus diameter after } 7 \mathrm{w} \text { subculture } \\
(\mathrm{cm})\end{array}$ & $\begin{array}{l}\text { Callus proliferation } \\
\text { scoring }\end{array}$ & Color of callus & $\begin{array}{l}\text { Morphology of } \\
\text { callus }\end{array}$ \\
\hline \multicolumn{5}{|l|}{$2,4-\mathrm{D}+\mathrm{Kn}$} \\
\hline $12,4-\mathrm{D}+0.5 \mathrm{Kn}$ & 1.0 & ++ & Brown & Frible \\
\hline $12,4-\mathrm{D}+1.0 \mathrm{Kn}$ & 2.2 & +++ & Brownish & Nodular \\
\hline \multirow{4}{*}{$12,4-\mathrm{D}+1.5 \mathrm{Kn}$} & 2.6 & ++++ & Green & Compact \\
\hline & & ++++ & Whitish & \\
\hline & & ++ & & \\
\hline & & +++ & & \\
\hline
\end{tabular}

'++++' Intense, ‘+++' Moderate, '++' Meager

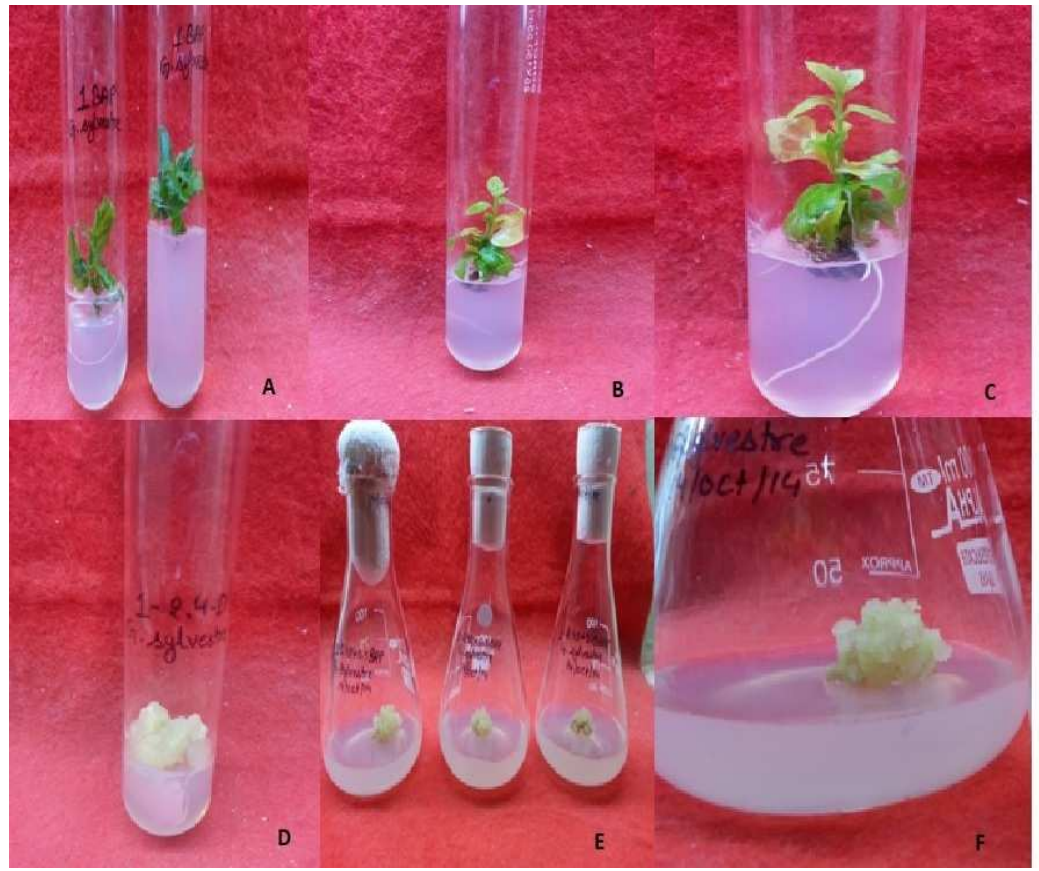

Fig. 1(A-F): Micropropagation of Gymnema sylvestre $\mathrm{R}$. Br. from nodal shoot explants

A. shoot multiplication on MS medium supplemented with 1.0 $\mathrm{mg} / \mathrm{l} \mathrm{BAP,} \mathrm{B.} \mathrm{Shoot} \mathrm{multiplication} \mathrm{on} \mathrm{medium} \mathrm{supplemented} \mathrm{with}$ $2.0 \mathrm{mg} / \mathrm{l} \mathrm{Kn}, \mathrm{C}$. Root induction on MS medium fortified with 2.0 $\mathrm{mg} / \mathrm{l}$ IBA, D. Callus induction on MS medium supplemented with
$1 \mathrm{mg} / \mathrm{l}$ 2,4-D, E. Callus multiplication on MS medium supplemented with $1 \mathrm{mg} / \mathrm{l}$ 2,4-D+0.5 mg/l BAP, F. Callus proliferation on MS medium Supplemented with $1.0 \mathrm{mg} / \mathrm{l}$ 2,4$\mathrm{D}+1.5 \mathrm{mg} / \mathrm{l} \mathrm{Kn}$.

Graph 1: Effect of cytokine (BAP) on shoot proliferation from nodal shoot explants of Gymnema sylvestre $\mathrm{R}$. Br

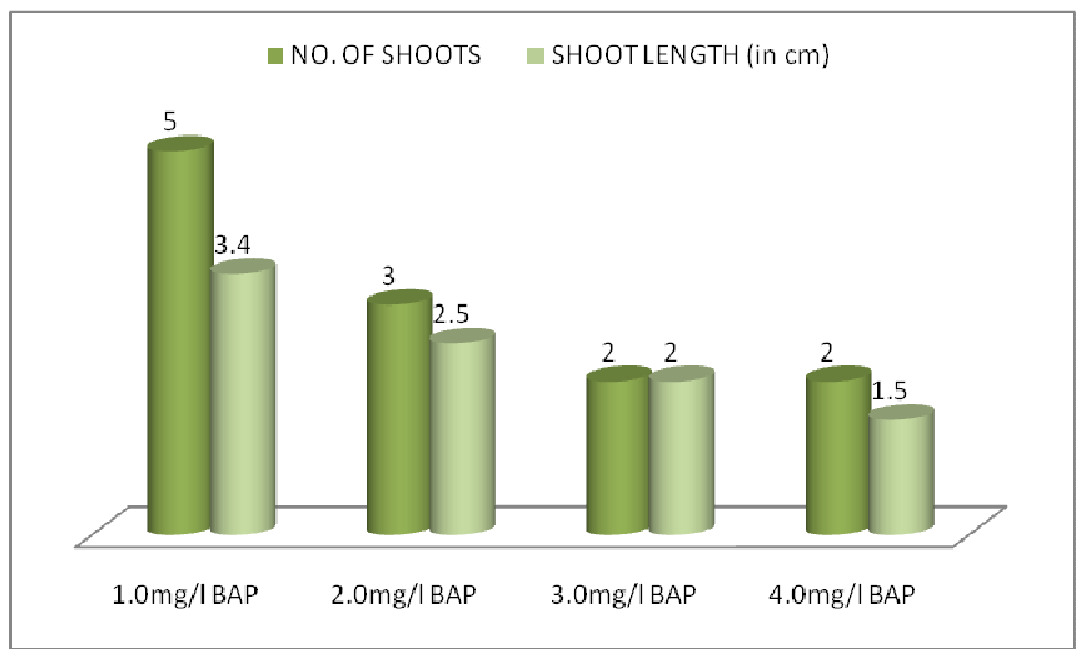


Graph 2: Effect of cytokine (Kn) on shoot multiplication by a subculture of shoot clumps of Gymnema sylvestre $\mathrm{R}$. Br

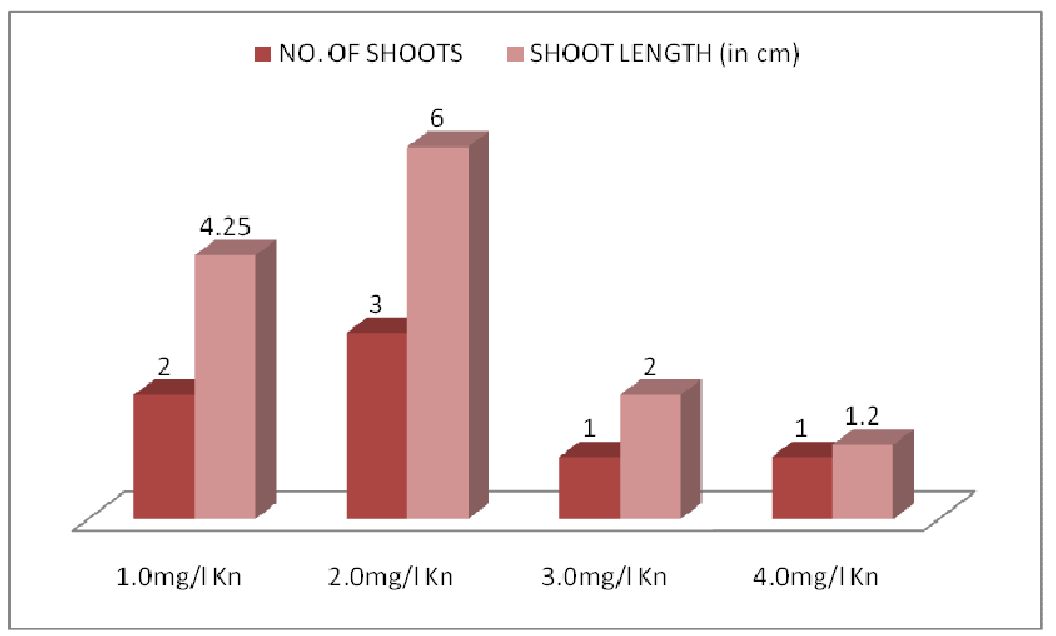

Graph 3: Effect of Auxin (IBA) on root induction from isolated shoots of Gymnema sylvestre $\mathrm{R}$. Br

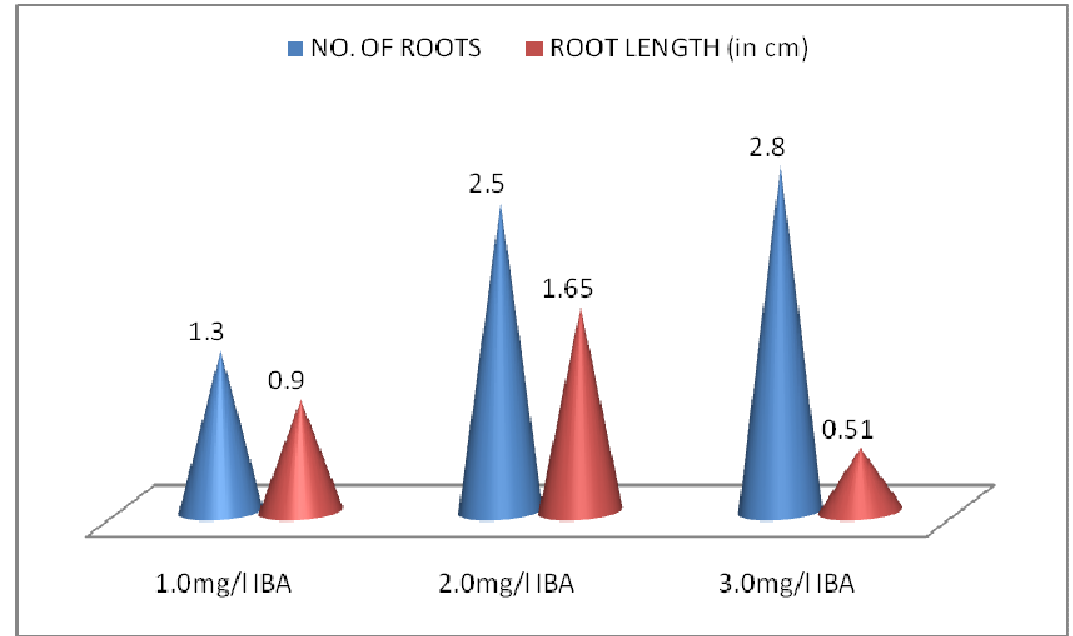

\section{CONCLUSION}

Juvenile seedling derived explants are used for micropropagation because they are easy to establish in culture. Explants were cultured on MS medium fortified with different concentrations of Cytokinin (BAP and $\mathrm{Kn}$ ). It was concluded from the observation that BAP with concentration $1.0 \mathrm{mg} / \mathrm{l}$ is better for culture initiation. And for mass multiplication of shoots $\mathrm{Kn}$ proved a better choice than BAP. A maximum number of shoots was obtained on $2.0 \mathrm{mg} / \mathrm{l} \mathrm{Kn}$ containing MS medium.

Plantlets were sub-cultured on MS medium containing various concentrations of IBA for root induction. From various observations, it was concluded that $2.0 \mathrm{mg} / \mathrm{l}$ IBA is best for in vitro rooting.

For the growth of callus, leaf explants were cultured on MS mediums containing different concentrations of 2,4-D. $1 \mathrm{mg} / \mathrm{l}$ 2,4-D gave good results in callus induction.

After the induction of callus, induced callus was sub-cultured on different concentrations and combinations of hormones to detect the various in the growth of callus. For this purpose, 2,4-D was fortified with BAP, 2,4-D with $\mathrm{Kn}$ and BAP with IBA were used. Among various sub-culturing on different concentrations $1.0 \mathrm{mg} / \mathrm{l} 2,4-\mathrm{D}+0.5$ $\mathrm{mg} / \mathrm{l} \mathrm{BAP,} 1.0 \mathrm{mg} / \mathrm{l}$ 2,4-D+1.5 mg/l Kn.

\section{ACKNOWLEDGEMENT}

I am grateful to Dr. Krishnendra Singh Nama for his sincere efforts in writing this research paper. I am also thankful to Plant Tissue
Culture Division of Vital Biotech Research Institute, Kota for providing laboratory facilities and also thankful to Mr. Jitendra Mehta of Vital Biotech for his help. I would like to thank the reviewers of this paper for their excellent comments.

\section{AUTHORS CONTRIBUTIONS}

All the author have contributed equally

\section{CONFLICT OF INTERESTS}

Declared none

\section{REFERENCES}

1. Anonymous. Indian Medicinal Plants: a sector study. Occasional paper No. 54. Export-Import Bank of India. Quest Publication, Bombay, India; 1997.

2. Syedy Mohsina, Nama KS. Gymnema sylvestre: a miracle fruit for a diabetes cure. Int J Pure Appl Biosci 2014;2:318-25.

3. George EF, Sherrington PD. Plant propagation by tissue culturehandbook and directory of commercial laboratories. Exegetics Ltd., Edington; 1984.

4. Rout GR, Sanghamitra S, Das P. Effects of chromium and nickel on germination and growth intolerant and non-tolerant populations of Echinochloa colona (L). Chemosphere 2000;40:855-9.

5. Sharma Bharti, Bansal YK. In vitro propagation of Gymnema sylvestre Retz. R. Br through apical bud culture. J Med Plants Res 2010;4:1473-6. 
6. Shrivastava R, Pratibha S. In vitro propagation of multipurpose medicinal plant Gymnema sylvestre $\mathrm{R}$. Br. (Gudmar). Indian J Shodha anusandhan Samachar 2011;1:27-30.
7. Pandey Ashok K. Cultivation technique of an important medicinal plant Gymnema sylvestre R. Br. (Gurmar). Acad J Plant Sci 2012;5:84-9. 